210 görülür. Sıklıkla kullanılan terimler ve eski sözcükler için zaman zaman metin içinde açıklamalar vardır ve kitabın sonunda bir lügatçe yer alır.

Hacimli ve bol görselli olan kitabın tasarımı okuyucu için göz okşayıcıdır. Metin içinde referans verilen resimlerin yerleşimi metinle görselin birlikte algılanmasına olumlu katkı yapar. Katalog kısminda ise her eserin olmasa bile büyük çoğunluğunun birden fazla görseli ve imza, mühür gibi kayıtlarıyla tezhip ya da diğer sanatsal niteliklerinin ayrıntılı resimleri yer alır. Bu açıdan kitap doyurucu bir görsel içeriğe sahiptir.

Zeren Tanındı giriş metninde, SHM koleksiyonundaki ayrıntılarıyla incelediği eserlerin pek çoğunun ayrı ayrı monografik çalışmalara konu olabileceklerini vurgular. Zira koleksiyondaki kimi eserler dönemin seçkinlerinin ince zevklerine, sanatçı-hami ilişkilerine, sanatlı kitap kültürünün aydınlanmasına katkıda bulunacak değerdedir. Titiz bir çalışma ile ele alınan Yazıda

\section{Christopher Houston, Istanbul, City of the Fearless: Urban Activism, Coup d'État and Memory in Turkey. Oakland: University of California Press, 2020. xii +227 pages, 3 figures. ISBN: 9780520373191}

What is urban activism good for? How should we understand, conceptualize, and study it? What is "urban" in urban activism? What makes it a distinctly political enterprise? These are some of the basic questions that have been occupying urban theory and social movement scholarship since Manuel Castells' seminal work, The Urban Question. ${ }^{1}$ Together with Henri Lefebvre, Castells was one of the first to discover the potential of urban space for mobilizing grievances in an effective and political way. While Castells' interest in urban question has subsided later on, the unique role of urban space in shaping and representing social contract has continued to fascinate scholars. This interest took
Âhenk ve Renk: Sadberk Hanım Müzesi Koleksiyonundan Sanatl Kitaplar, Belgeler ve Hüsn-i Hatlar, hüsn-i hatta ilişkin zengin içeriği, ilk kez yayımlanan eserlerle ilgili tanıtımları ve farklı disiplinlerden araştırmacılara sağladığı veri açısından özgün ve çok katmanlı bir kitaptır. Öne çıkan örneklerin ve sanatçılarının değeri, koleksiyonun pek çok nadide ve biricik eserden oluşması, koleksiyonerin zevkinin ve bilgisinin de göstergesi olarak görülebilir. Yazıda Âhenk ve Renk, sanatlı kitap biriktirme geleneği ve kültürünün, üçüncü kuşak taşıyıcıları aracılığıyla günümüze ulaştırdıkları eserleri daha ayrıntılı tanımaya olanak verir.

\section{Aslihan Erkmen \\ İstanbul Teknik Üniversitesi \\ erkmena@itu.edu.tr}

1 Serpil Bağcı, "Metinlerden Resimlere: Elyazma Tasvirlerinde Hz. Ali," İslam İnançlarında Hz. Ali, der. Ahmet Yaşar Ocak (Ankara: Atatürk Kültür, Dil ve Tarih Kurumu ve Türk Tarih Kurumu, 2005), 218-220.
2 Son y1llarda hem Türkiye'de hem de dünyada teknolojik gelişmelerin hızlanması ve dijital iletişim olanaklarının yaygınlaşmasıyla birçok yazma eser koleksiyonu uzaktan erişime açılırken, kimi koleksiyonların da ayrıntılı katalogları yayımlanmıştır. Yakın örnekler arasında Ayşe Aldemir Kilercik ve Zeren Tanındı, Sakıp Sabancı Müzesi Kitap Sanatlart ve Hat Koleksiyonu (İstanbul: Sakıp Sabanc1 Müzesi, 2012); Günay Kut et al., İstanbul Araştırmaları Enstitüsü Yazmaları Kataloğu, 3 c. (İstanbul: İstanbul Araştırmaları Enstitüsü, 2014) sayılabilir. İstanbul Araştırmaları Enstitüsü’nün bu koleksiyona dayanarak 2019'da açtı̆̆ $\mathrm{Haf} ı z a-i$ Beşer: Osmanlı Yazmalarından Hikâyeler sergisi Google Arts \& Culture üzerinden sanal olarak da gezilebilmektedir, bkz. https://artsandculture. google.com/story/haf\%C4\%B1za-i-be\%C5\%9Fer/_ALC-C 4 OOd14JQ?hl=tr, erişim 22 Ağustos 2020. Bu gelişmeler, bir yandan çağdaş müzecilik uygulamalarının, bir yandan da yazma eserlere yönelik ilginin artmasının bir sonucu olarak yorumlanabilir.

3 Sadberk Hanım Müzesi 14 Ekim 1980 tarihinde, İstanbul Sarıyer'deki Azaryan Yalısı'nda hizmet vermeye başlamıştır.

$4 \mathrm{Bu}$ incelemeye konu olan iki ciltlik kitapta koleksiyondaki tüm eserlerin değerlendirmesi yapılmıştır. Sergide ise bunlar arasından seçilen 134 eser yer almıştır ve sergi için daha dar kapsamlı bir katalog hazırlanmıştır. Bkz: Zeren Tanındı, Yazıda Âhenk ve Renk: Sadberk Hanım Müzesi Koleksiyonundan Sanatl Kitaplar Belgeler Hüsn-i Hatlar / Harmony of Line and Colour: Illuminated Manuscripts Documents and Calligraphy in the Sadberk Hanım Museum Collection, çev. Mary Işın (İstanbul: Vehbi Koç Vakfı, Sadberk Hanım Müzesi, 2019). a particular upsurge in the past decade as urban occupations, revolt, and uprisings have become commonplace across the world from 2010 onward. ${ }^{2}$

Concentrating on the period leading up to the coup of 1980 and its immediate aftermath, the urban activism that Christopher Houston narrates in Istanbul, City of the Fearless belongs to a different era, one in which urban activism in fact was neither seen as necessarily urban nor named as activism, certainly not in Turkey. Yet by framing the popular left-wing mobilizationand right-wing counterinsurgency-of the 1970 as a form of urban activism, Houston's book is a bold invitation. It certainly yields successful results in understanding not only the timeframe it chooses to examine but also the making of modern Istanbul, as well as urban activism. As such, Istanbul, City of the Fearless provides an illuminating perspective to the often forgotten building blocks of the city: everyday politics and political violence of the 1970 .

Houston's book is a phenomenological take on political mobilization, violence, and memory, prioritizing the voices and reckonings of activists themselves. Rather than a remote and top-down analysis, the book centers around the very actors and subjects of that violence, asking directly to more than fifty informants, veteran political militants of 1970s' Istanbul, how they remembered the city, made sense of the political mobilization of the time, and how they were involved. As such, the book differs in methods and perspective from the conventional accounts of the coup of 1980 , one of the defining events of modern Turkish history. While the official narrative suggests the military intervention was almost an inevitable outcome of the street violence of rival political groups, Houston unpacks the logic and inner workings of violence. Houston's phenomenological anthropology helps him immensely in this endeavor as the emphasis on human intentionality and embodied experiences really illuminates the era, details of which are invisible due to prejudice and stigma or over-romanticization.

The spatial focus of Istanbul, City of the Fearless is what makes the book a unique contribution to the field. Houston takes the political role of space 
seriously, both in symbolic and literal senses. The book not only examines which political faction was strong in what neighborhood, but also traces the impact of political mobilization on how the city has developed and how its residents have experienced it. While the former details are widely circulated among Istanbulites as urban legends, the latter originally weaves together Istanbul's urban experience with its grassroots politics. Engaging with a number of theorists of space, including Lefebvre, de Certeau, and Tschu$\mathrm{mi}$, Houston conceptualizes what is easily brushed over as street violence between the opposing left and right (sometimes left and left) factions as a spatial politics. As such, political violence cedes to be an exception that was dealt with once and for all by a military intervention; it is understood as part and parcel of the city's social and spatial history. While doing so, Houston refrains from equating spatial politics with the activities of the organized political groups; he also recognizes the autonomy of urban migrants who by choice (or willy-nilly) cooperated with them, although the research is limited to the activists' perspectives.

Istanbul, City of the Fearless is organized across eight chapters. Following two introductory chapters in which Houston lays out the theoretical and methodological underpinnings of the study (including the focus on space and use of phenomenology), the third chapter reviews the top-down urban planning policies of the republican era until the mid-1970s (including attempts towards de-Ottomanization and Turkification of Istanbul), which Houston criticizes as "violence of architecture" (p. 5). Chapters 4 and 5 are where Houston makes the best use of his ethnographic data by depicting in rich detail how political activism shaped the urban land and soundscape of Istanbul in the 1970s. With its focus on the factory-council-squatter nexus, I found chapter 5 particularly intriguing and easily assignable to urban studies and social movements classes. Chapter 6 lays out, for the first time for many English-language readers, the competing ideologies and political strategies of revolutionary left factions (also the anti-communist, right-wing movements) in Turkey in the 197os. Chapter 7 focuses on the coup of 1980 and its aftermath and traces the impact of the military intervention not simply over the political and institutional realm, but also in urban bodies, places, and communities. The book concludes with chapter 8, in which Houston revisits the potentials opened up by phenomenology for the study of political violence in Istanbul. In this chapter Houston also follows his informants in present time and discusses how they today wrestle with the memory of the 1970s and the burden of the coup.

Despite these accomplishments, there are certain aspects of the book that are prone to criticism. The first point of critique is relatively minor. Despite its emphasis on space and place, it is unfortunate that Istanbul, City of the Fearless does not make much use of visuals and maps to give the reader a better sense of the city and the physical distribution of forces that shaped it throughout the 1970 . The book only includes three figures, two of which are hand drawings by the author. While I appreciate the fieldwork feel of them, it is hard to say that they help the reader in any way. Since the book leads the reader through the many neighborhoods, streets, and squares of one city, the lack of cartographic visuals is a missed opportunity for Istanbul, City of the Fearless.

My second point of critique is more substantial. While Istanbul, City of the Fearless is a historical inquiry into the late 1970 s and early 1980 os, it should also be noted that, in some ways, it is influenced by the time in which it was researched and written. Those who observe Turkish politics closely can easily detect that dominant discourses of the early 2010 s that often find their way into the narrative of the book. The way the book identifies the role of the military and bureaucracy in Turkish politics, as well as Kemalism as the source of authoritarianism and chauvinism, seems to borrow much from the hegemonic narrative of the first decade of the Justice and Development Party's (AKP) reign. For example, the trial of the 1980 coup plotters, which turned out to be a mere carrot to motivate the left to support the government-backed 2010 referendum for constitutional amendment, is largely treated in a positive light. The damage and schism the referendum created within revolutionary left politics is not elaborated on. ${ }^{3}$ This is perhaps understandable as the focus of the book is not the political climate of the early 2010s, but rather how the 1970 ore remembered by a group of urban activists. However, memory often tells as much about today as it does about the past. In this case, this is valid for the researcher, as well. Readers of Istanbul, City of the Fearless in 2020's Turkey, where public institutions are completely dominated and the social and political realm utterly suppressed by the AKP, may raise their eyebrows to some of the book's insights and lack of reckoning with the democratic backsliding under a civilian government.

The urban problems of Istanbul and the social mobilization that they instigate has been a popular theme for social scientists working on Turkey for a while now. Yet, the existing literature is captivated by the Gezi moment-perhaps understandably so-and its accounts often fail to go beyond contemporary matters and debates. Istanbul, City of the Fearless provides a fresh perspective in this regard. In an eloquent way, it reminds us of the historical layers of Istanbul's social and spatial development and suggests that urban activism may not be entirely a brand new enterprise. What is the legacy of the urban activism of the 1970 os for current urban struggles in Istanbul? How does the spatial politics of the past reverberate in contemporary Istanbul? These are some of the intriguing questions that Istanbul, City of the Fearless poses to Istanbul studies.

\section{Sinan Erensü}

Boğaziçi University

sinan.erensu@boun.edu.tr

1 Manuel Castells, The Urban Question (Cambridge: MIT Press, 1977).

2 David Harvey, Rebel Cities: From the right to the city to the urban revolution (London: Verso, 2012); Mustafa Dikeç, Urban Rage: The Revolt of the Excluded (New Haven: Yale University Press, 2017); Donatella Della Porta, Global Diffusion of Protest: Riding the Protest Wave in the Neoliberal Crisis (Amsterdam: Amsterdam University Press, 2017); Mustafa Dikeç and Erik Swyngedouw, "Theorizing the politicizing city," International Journal of Urban and Regional Research 41, no. 1 (2017): 1-18; Andy Merrifield, The Politics of the Encounter: Urban Theory and Protest under Planetary Urbanization (Athens: University of Georgia Press, 2013).

3 More on this critical period see Aslı Bâli, "Unpacking Turkey's 'Court-Packing' Referendum," Middle East Report Online 5 (2010); İsmet Akça, "AKP, Anayasa değiş̧ikliği referandumu ve sol: 'Yetmez ama evet'in açmazları," Mesele 45 (2010): 1-19; Ersin Kalaycıŏlu, "Kulturkampf in Turkey: The constitutional referendum of 12 September 2010," South European Society and Politics 17 , no. 1 (2012): 1-22. 